\title{
The Reform and Practice of Talent Training Mode Based on the Criteria of Engineering Education Accreditation
}

\author{
SHEN Jianqiang, SI Chengyong, ZOU Xuan and LI Taoning \\ Sino-German College \\ University of Shanghai for Science and Technology \\ Shanghai, China
}

\begin{abstract}
On the basis of experience in passing the engineering education accreditation organized by ASIIN(German Accreditation Agency for Study Programs in Engineering) and fully analyzing the criteria for domestic engineering education accreditation, the main requirements of the criteria are classified in this paper. Furthermore it puts forward the model of rising teaching quality with circular mechanism based on inner and outer loops of teaching process and other effective reforms in terms of the essential of the teaching quality control for engineering education accreditation. We expect all the practical experience and measures presented in this paper will be beneficial to passing the engineering education accreditation and implementing the reform of talent training mode based on the criteria of engineering education accreditation.
\end{abstract}

Keywords-Engineering Education; Accreditation; Talent Training Mode; Outcome-based Learning

\section{INTRODUCTION}

Washington Accord is an international accreditation agreement for professional engineering academic degrees, between the bodies responsible for accreditation in its signatory countries. The agreement recognizes that there is substantial equivalence of programs accredited by those signatories. Graduates of accredited programs in any of the signatory countries are recognized by the other signatory countries as having met the academic requirements for entry to the practice of engineering. Recognition of accredited programs is not retroactive but takes effect only from the date of admission of the country to signatory status ${ }^{[1]}$.

With the June 2016 China admitted as a formal signatory country by Washington Accord, it provides international recognition of the quality standard of "pass" for Chinese engineering students, also symbolizes the internationalization of engineering education in China has made great strides. Meanwhile It means our higher engineering education is facing opportunities and challenges. Undoubtedly it is crucial to improve the level of higher engineering education and international competitiveness of manufacturing industry in China.

The Objective to carry out the engineering education accreditation is to construct the quality monitoring system of engineering education in China; to further improve the quality of engineering education; to establish professional education system combining registered engineer system; to enhance the talent's adaptability of enterprises industrial development; to promote international recognition of domestic engineering education and the international competitiveness. All in all, the core of engineering education accreditation is to establish the student-oriented education quality monitoring system and concurrently to form the circular rising mechanism for teaching quality improvement ${ }^{[2]}$.

It can be foreseen that more and more domestic engineering specialties will take the engineering education accreditation standard as the goal, and implement the reform of talent training mode, so as to improve the teaching quality of engineering specialty. However, at this stage, some domestic engineering specialties intending to accept engineering accreditation are not so clear to the criteria of engineering education accreditation; how to change their training goal and the teaching process to adapt to the demand of engineering talents who enterprises really need ${ }^{[3]}$. The core concept of talent training in engineering education accreditation is "Outcome-based Learning", that is, converting "what can a teacher teach?" to "what should students achieve?", regarding "students" as the center of the design and implementation of teaching activities. It will be an important shift to cultivate the occupation-required abilities instead of teaching engineering knowledge in the training of higher engineering education.

On the basis of the requirements of the study and analysis of engineering education accreditation criteria and conditions, put forward the measures of teaching reform and feasible scheme. Meanwhile these measures should be continuously improved and optimized in the process of reform implementation and finally achieve effective experience. Therefore, it will be a meaningful and important to share the successful experience with others.

The Sino-German Cooperative electrical engineering and automation specialty of University of Shanghai for Science and Technology was awarded "Shanghai Model International Cooperative Education Program" in 2012, and it started quite early accepting international engineering education accreditation. In 2004, ASIIN (German Accreditation Agency for Study Programs in Engineering) appointed the expert group to the University of Shanghai for Science and Technology for an on-site assessment. The specialty passed 
the first-time accreditation and obtained the certification is valid for the next five years. This is the first case of the accreditation held by ASIIN in Asia ${ }^{[4]}$. By 2010, our specialty accepted the second-time accreditation and unconditionally had passed the accreditation again. The certification is valid for eight years and expiring in 2018. That means our specialty has the qualification to issue both Chinese and German bachelor degrees for our qualified graduates in China during the following eight years.

On the other hand, ASIIN is the European system of engineering education certification agencies and is also a member of the Washington Accord ${ }^{[5]}$. The two accreditation systems have the nearly same core and framework of accreditation criteria which is so-called "Outcome-based Learning" principle ${ }^{[6]}$. As a result, graduates from the specialties successfully accredited by ASIIN will have the Engineer qualification not only in the European Union ,but in the United States, Canada, Australia, Japan and other the " Washington Accord" signatory countries. Furthermore the domestic engineering education accreditation is as basically same as German ASIIN in the accreditation objective, criteria as well.

In the following part of this paper, we shall conclude our experience in ASIIN accreditation and make a brief introduction to the effective measures for reforming talent training mode based on the criteria of engineering education Accreditation.

\section{REFORM AND PRACTICE OF INTERNATIONALIZED AND APPLIED TALENTS TRAINING MODE}

The biggest difference between our specialty and other domestic international cooperative education programs is $4+0$ mode. Namely, four years of undergraduate education can be done in China (except for a few outstanding students through the selection to practice in Germany). In order to achieve the same level of teaching quality of German engineering university, it is necessary to entirely introduce the training mode of German engineering education and teaching management system. It is very crucial for engineering applied majors to introduce German practice teaching ideas, mode and experimental platform. In terms of the accreditation objective, criteria and requirements, our specialty presented the specific solutions and relevant reform initiatives ${ }^{[7]}$ as follows:

\section{A. Build the Internal and External Quality Control Mechanism in the teaching process}

The engineering education accreditation criteria and indicators show that the improvement of engineering education quality is an important quality conception; regular activity of quality improvement and it can occur in any links of teaching process. To Improve quality control mechanism in the teaching process, It must take students as the center and build quality monitoring and continuous improvement mechanism, The mechanism consists of two aspects in our talent training model. They are the internal and external quality control circles. The internal quality control is to establish a quality control team inside the specialty. The members of the team are from representatives of each-grade students, three teachers (including the head of the specialty) in the specialty and an education expert.

The quality control team regularly discusses and evaluates curriculum system, current situation of teaching quality and proposes some suggestions for quality control measures; External quality control is to set up a "enterprise advisory committee", The members of this committee are representatives from the enterprises accepting our students' internship and absorbing our graduates. At the same time, we established the mechanism for graduates' tracing feedback and social evaluation to carry out regular investigation. Through internal and external quality control mechanism, continuously find the problems in the teaching process, then improve teaching content mode, management and finally ensure the quality of students to meet the requirements of engineering the accreditation criteria. Fig. 1 illustrates the rising quality model with circular mechanism based on inner and outer loops of teaching process. Table 1 shows the corresponding reform measures were implemented to meet the requirements and criteria of the engineering education accreditation.

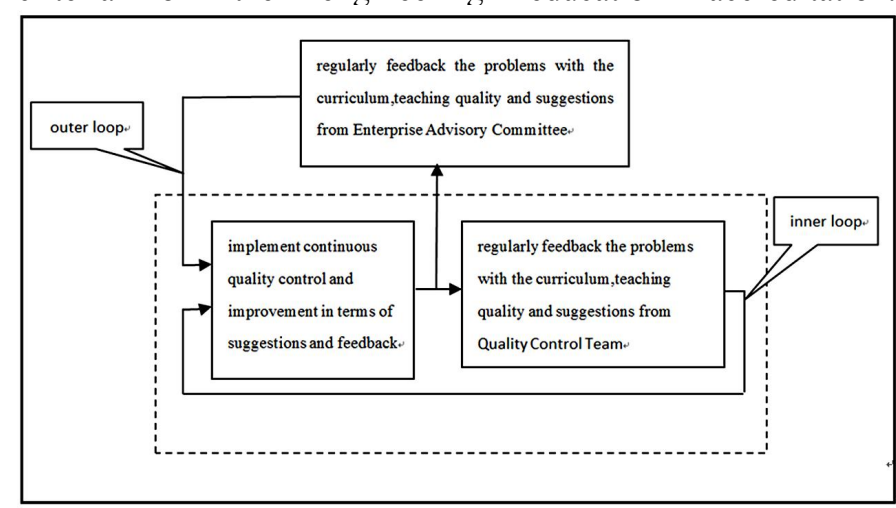

Fig. 1. Rising quality model with circular mechanism based on inner and outer loops of teaching process

\section{B. Reduce the gap between students' working ability and enterprises requirements}

The engineering education accreditation criteria emphasizes "Outcome-based Learning" and "cultivating the ability to solve system and complex problems ", its ultimate goal is to ensure the students can meet the requirements in the corresponding occupation. Namely what students learn is what they need in industrial enterprises. Moreover guarantee the graduates are qualified in their work after a certain period of time and can continue to maintain and improve their occupation ability through training to improve the skills ${ }^{[8]}$. This requires the training objectives should be set up according to the requirements of promoting students' practice ability, as well as keeping this kind of ability a period of time after graduation. At the same time, the curricula, teachers and teaching conditions should help and lead students to achieve the goal of training and graduation requirements. To enable students to own engineering practice, innovative ability and keep up with the actual needs of enterprises and industry development, it is necessary to reform the curriculum, teaching content and talent training mode. For this purpose, our specialty refers to engineering education accreditation 
criteria and take corresponding measures as the following aspects:

TABLE I. CORRESPONDING MEASURES IMPLEMENTED TO MEET THE REQUIREMENTS AND CRITERIA OF ACCREDITATION

\begin{tabular}{|c|c|c|c|}
\hline $\begin{array}{l}\text { accreditation } \\
\text { criteria and } \\
\text { corresponding } \\
\text { measures }\end{array}$ & $\begin{array}{l}\text { requirements } \\
\text { of } \\
\text { accreditation } \\
\text { criteria }\end{array}$ & \multicolumn{2}{|c|}{ corresponding reform measures } \\
\hline 1 & $\begin{array}{l}\text { compared with } \\
\text { all aspects of } \\
\text { the criteria, } \\
\text { specialties must } \\
\text { clearly } \\
\text { understand the } \\
\text { problems } \\
\text { existing and } \\
\text { have the } \\
\text { internal and } \\
\text { external ways to } \\
\text { obtain } \\
\text { information }\end{array}$ & $\begin{array}{c}\text { internal } \\
\text { channel to } \\
\text { understand } \\
\text { the problems } \\
\text { and obtain } \\
\text { information : } \\
\text { the quality } \\
\text { control team }\end{array}$ & $\begin{array}{l}\text { external channel } \\
\text { to investigate } \\
\text { information: } \\
\text { enterprise } \\
\text { advisory } \\
\text { committee }\end{array}$ \\
\hline 2 & $\begin{array}{c}\text { clear and } \\
\text { feasible } \\
\text { improvement } \\
\text { mechanism and } \\
\text { measures }\end{array}$ & \multicolumn{2}{|c|}{$\begin{array}{l}\text { regularly hold quality control and } \\
\text { enterprise advisory meetings, } \\
\text { have clear and feasible } \\
\text { improvement mechanisms and } \\
\text { measures }\end{array}$} \\
\hline 3 & $\begin{array}{l}\text { able to track the } \\
\text { results of the } \\
\text { improvements } \\
\text { and collect } \\
\text { information for } \\
\text { further } \\
\text { improvement, } \\
\text { which is a } \\
\text { cyclical rising } \\
\text { for continues } \\
\text { quality } \\
\text { improvement. }\end{array}$ & \multicolumn{2}{|c|}{$\begin{array}{l}\text { the quality rising with circular } \\
\text { mechanism based on inner and } \\
\text { outer loops of teaching process } \\
\text { (see Fig. 1) }\end{array}$} \\
\hline
\end{tabular}

1) Reforming the teaching content in terms of the requirements of enterprises

The traditional experiments of engineering courses in our country mainly focus on mastering each single knowledge point as the goal and the experimental process is mostly based on the principle of verification. It is far from the actual scene of enterprises. Absorbing the advanced experience and experimental mode of engineering practice education in Germany, our specialty reformed the curriculum and its experimental content with the guidance of engineering application and innovation. From the experimental equipment to the experimental content, even the configuration of experimental platforms in laboratories are much close to the industry environment, so as to create the conditions for students to easily adapt to requirements of enterprise as soon as possible. Taking two core courses , "Power Electronics" and "Electric Drive", as an example, domestic teaching instrument factories only provide small-power motors as experiment device, they are called motors in toys by German professors. All of our experiments use the big-power motors like ones in actual enterprises

2) Integration and reconstruction of knowledge system course groups and curriculum system

In order to cultivate students' ability to solve systems and complex problems, it is necessary to design the curriculum system as a whole. The traditional experiments are basically aimed at the specific theoretical courses; the experiments of different courses are relatively split and lack of connections. The experimental teaching system based on engineering education accreditation tries to build the close connections among the content of courses and their experiments. In other words, the students can comprehensively apply the new and previous knowledge or technologies to design and complete systematic experiments. Finally students have the ability to solve the system and complex problems through project design and graduation design.

In addition, it is a gradual process and needs a series of teaching activities to cultivate the ability to solve systematic and complex problems. For example, invite engineers from enterprises to guide experiments or give lectures; make use of industrial products donated by enterprises and cooperate with enterprises to construct joint laboratories; establish E-learning distance education platform; support students' innovative activities and so on.

\section{Concentrate on the cultivating professional quality of engineer and international vision}

Both Washington Accord and the engineering accreditation of our country have specific provisions on cultivation of professional quality and international vision. Engineering undergraduates should have the abilities and characteristics such as effective communication, cooperation skills, lifelong learning, teamwork, international vision and sense of responsibility, understanding, solving issues related with environmental, economic and social engineering. What is more, the accreditation criteria pointed out that these quality requirements are the part of certification standards and the indicators which must be focused on. The German ASIIN engineering accreditation criteria also require that students should be encouraged to acquire foreign language ability, so that they can be active and competitive in the international environment after graduation ${ }^{[9]}$.

Regarding to cultivate professional quality of engineer and strengthen students' international competitiveness in the future, our specialty targeted reforms in the following points:

- Inviting managers or engineers of enterprises to offer lectures on the professionalism of engineers.

- Organizing students in a team way to complete innovative activities, project design and comprehensive large-scale assignments.

- Strengthening technical English teaching, language expression and communication skills.

- Encouraging students to apply the methods of project management to project design and development in the " Project Design " course.

- Arranging as many students as possible to complete their internship and graduation design (thesis for the Bachelor Degree) in a foreign enterprise, so as to improve students' intercultural communication and working adaptability, and so on. 


\section{CONCLUSION}

Accreditation of engineering education is an international system of engineering education quality assurance, and also an important basis for international mutual recognition of engineer qualification.

Based on the engineering education accreditation criteria, the reform of internationalized and applied talents' training mode was carried out in our specialty. Under guidance of student-oriented and outcome-based learning, established the quality control and feedback control mechanism of the teaching process. In this case, the each main teaching link has a clear quality requirement. It will promote to achieve the training objectives. By strengthening the cooperating with industry enterprises, students can improve their engineering practice ability, innovation ability, work adaptation ability, professional ability and professional quality of engineer to meet the needs of enterprises. Meanwhile, in order to cultivate international, applied, compound and innovative talents, it is necessary for us to explore and accumulate experience of engineering teaching and to share the experience with others.

\section{REFERENCES}

[1] Sun Hui, Xia Jianguo, "International Engineering Education Accreditation and its implications for China's higher education reform, " Vocational Education Forum, vol. 7, 2010, pp. 33-35. (In Chinese)

[2] Fang Zheng, "A comparative study of engineering education accreditation system for signatory countries of Washington Accord, " vol. 4. Development and evaluation of Higher Education, 2014,pp.66-76. (In Chinese)

[3] Fang Zheng, "Internationalization of Engineering Education Accreditation in China, "vol. 6. Higher engineering education research, vol. 6, 2013,pp.72-76. (In Chinese)

[4] Feng Hui, "Shanghai international cooperative education case selection, " East China Normal University Press,2016,pp.80-87. (In Chinese)

[5] Jia Weiping, "Construction of engineering talent training system under the background of Engineering Education Accreditation, " Experimental technology and management, vol. 1, 2015,pp.38-40. (In Chinese)

[6] Lin Jian, "Construction of engineering talent training system under the background of Engineering Education Accreditation, " Engineering education accreditation, engineering education reform and development, vol. 2, 2015,pp.10-19. (In Chinese)

[7] Li Ruixiang, "Shanghai international cooperative education style album, "East China Normal University Press, 2014,pp.65-77.

[8] Wang Lin,Lei Huan, "Characteristics of engineering education accreditation of signatory countries of Washington Accordand and its inspiration to China, " Education research of Tsinghua University, vol. 5 , 2008,pp.88-92(In Chinese)

[9] Accreditation Agency for Degree Programmes in Engineering, Informatics/Computer Science, the Natural Sciences and Mathematics e.V. ,Criteria for the Accreditation of Degree Programmes - ASIIN Quality Seal,2015. (In Chinese) 